\title{
AN OCEANOGRAPHIC PERSPECTIVE ON EARLY HUMAN MIGRATIONS TO THE AMERICAS
}

By Thomas C. Royer and Bruce Finney

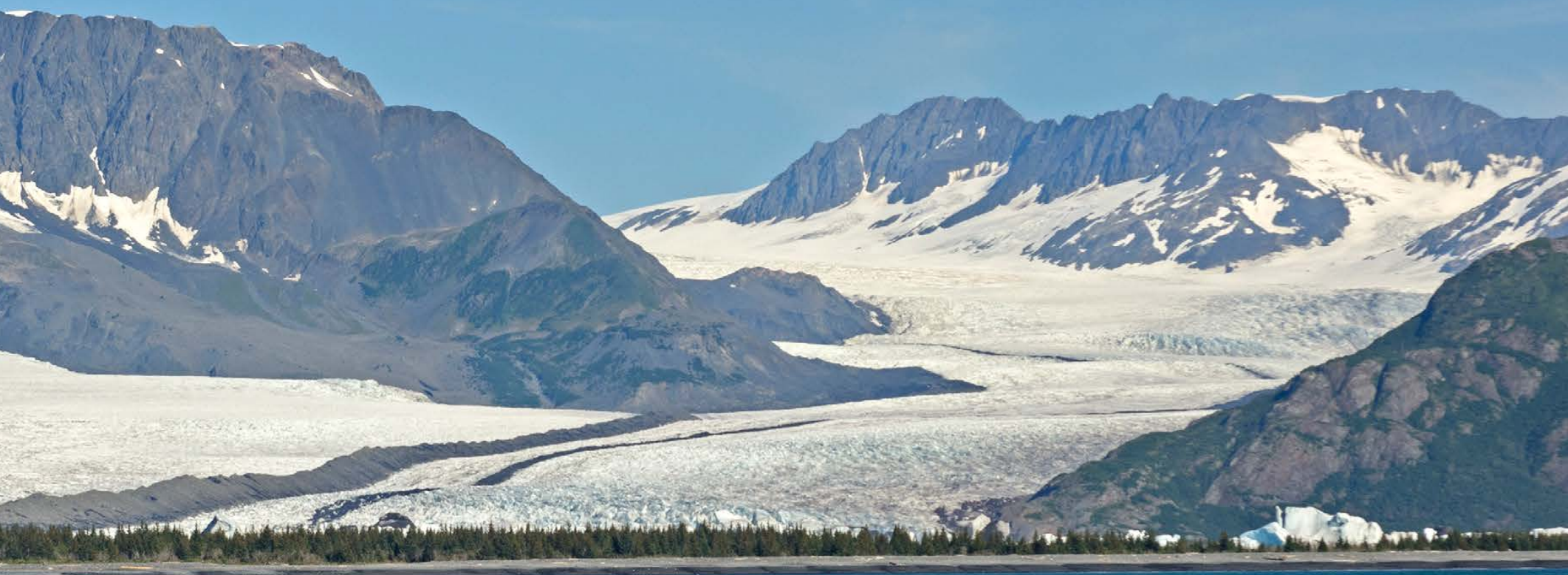




\section{Any migration during the Last Glacial Maximum and early deglaciation period may have been facilitated \\ by altered coastal currents, which would have favored such travel for only a few millennia.}

ABSTRACT. Early migrants to the Americas were likely seaworthy. Many archaeologists now agree that the first humans who traveled to the Americas more than 15,000 years before present (yr BP) used a coastal North Pacific route. Their initial migration was from northeastern Asia to Beringia where they settled for thousands to more than ten thousand years. Oceanographic conditions during the Last Glacial Maximum (18,000-24,000 yr BP) would have enhanced their boat journeys along the route from Beringia to the Pacific Northwest because the influx of freshwater that drives the opposing Alaska Coastal Current was small, global sea level was at least $120 \mathrm{~m}$ lower than at present, and necessary refugia existed. The onset of the BøllingAllerød warming period, between 15,000 yr BP and 14,000 yr BP, accelerated the melting of the Cordilleran Ice Sheet. Rapid increases in freshwater influx would have hindered travel along the coast of Alaska and British Columbia as global sea levels rose $14-18 \mathrm{~m}$ in 340 years, submerging refugia that had been used as haul-out locations. The northward-flowing Alaska Coastal Current accelerated, making southward movement along the coast less likely. An increase in the challenges to migration beginning with the Bølling-Allerød until the Younger Dryas (12,800-11,600 yr BP) likely occurred and could have resulted in a migration hiatus.

\section{INTRODUCTION}

Possible routes taken by the first humans entering North America from northeastern Asia are a lively topic of discussion within the archaeological community. Two routes are most commonly proposed. One is an overland route across the Bering land bridge and subsequently between the Cordilleran and Laurentide Ice Sheets, and the second is a coastal route along the perimeter of the North Pacific Ocean from Beringia, a grassy tundra region that stretched between what are now Alaska and eastern Siberia and included some parts of each. Although this controversy has not yet been fully resolved, many in the archaeology community now agree that the first human inhabitants reached the Americas via the coastal route before at least 14,600 years before present (yr BP; Wheat, 2012; Braje et al., 2017). Current research continues to support this hypothesis (e.g., Davis et al., 2019; Waters, 2019), even though until recently there was an absence of unambiguous artifacts to support the coastal route (Potter et al., 2018; McLaren et al., 2019). Braje et al. (2018) argued that such artifacts associated with the ocean route may be present though not yet found, as they would most commonly be many meters below current sea level. The focus of this paper is on the roles that oceanographic conditions played in initially helping and later hindering these early marine travels to the Americas.

\section{EARLY SETTLEMENT IN BERINGIA}

DNA-based evidence and controversial archaeological findings suggest that settlement in eastern Beringia began by about 24,000 yr BP (Bourgeon et al.,
2017; Moreno-Mayar et al., 2018; Waters, 2019), but there is no evidence for further resettlement at that time southward through eastern Beringia (Alaska, Yukon Territory). The new inhabitants to North America likely walked from northeastern Asia into Alaska because global sea level at that time was approximately $120 \mathrm{~m}$ lower than it is today. However, their path to the south was blocked by the Cordilleran Ice Sheet (CIS; Erlandson and Braje, 2011; Menounos et al., 2017), which extended from the present-day Aleutian island chain along the Gulf of Alaska coast south to about Seattle, Washington, and to the east to the western margin of the Laurentide Ice Sheet (Erlandson et al., 2008).

Coastal travel to Beringia was also possible, as supported by evidence of "island hopping" in the western North Pacific, consisting of obsidian trade, settlement, and shell middens in the vicinity of Japan as far back as 35,000 yr BP (Erlandson and Braje, 2011; Braje et al., 2019). Early migrations by boat along the North Pacific rim following the route inhabited by similar marine ecosystems are plausible. Such a coastal route is logical because the migrants would follow their food supply. The route, often referred to as the "kelp highway," is found along the Pacific coast from Japan to Mexico (Erlandson et al., 2007, 2015; Sutton, 2018). Archaeological and genomic data are also consistent with the concept that the Americas were colonized between 24,000 yr BP and 15,000 yr BP by humans who followed this North Pacific coastal corridor from 
Northeast Asia to the Americas (Braje et al., 2018). Walking for great distances along the shores of the Gulf of Alaska is virtually impossible today, and it would have been worse where glacial ice fields extended to the shoreline. The only possible southward path to the Americas was by water.

According to Erlandson et al. (2015), the coastal route was free of major obstructions after $\sim 16,000$ yr BP and presented few geological restrictions to human settlement. However, technological developments and oceanographic conditions might have affected the subsequent timing of early settlement of the Americas.

\section{BOAT TECHNOLOGY AND REFUGIA}

Migration south of Beringia required vessels that could carry people and their essential supplies through relatively cold waters and moderate sea states. Johnstone (1988, p. 5) surmises "Man undoubtedly used water-craft during the Paleolithic period, but we cannot say exactly what type of craft these were." Evidence of boat travel is based on obsidian use by people who traveled between Taiwan and Japan as long ago as 35,000 yr BP (Tsutsumi, 2007). However, open rafts or floating logs would not have been sufficient for human travel in cold, highlatitude waters. Settlement of the western North Pacific along the Kuril Islands at $17,000 \mathrm{yr} \mathrm{BP}$ would have required paddling between islands that averaged $26 \mathrm{~km}$ apart, with one pair of islands $66 \mathrm{~km}$ apart (Erlandson and Braje, 2011). Improved development of boat technology during the late Pleistocene era (ca. $<25,000$ years BP) was critical.

These early vessels must have been made from materials of local origin. The types of Pleistocene boats used near Japan could have been dugout canoes constructed using trees available from local forests. The scarcity of trees in Beringia required that the vessels would have been skin boats constructed from the hides of mammals, probably marine, for the outer shell and mammal bones or driftwood for their structural members (Dixon, 2000). Only primitive tools would have been necessary and an ability to sew skins together, a skill that the inhabitants of this relatively cold climate would have already possessed (Hoffecker, 2005), because needles and thread were necessary for their clothing. This boat development by the maritime population in Beringia is reasonable, though no historical evidence of it exists today because these materials are highly biodegradable. The skin boats, similar to modern kayaks and umiaks, would have been quite seaworthy, but would have had a serious duration limitation because the skins would have become waterlogged after 24-36 hours in the sea (Braund, 1988). Assuming constant paddling averaging $3 \mathrm{~km} \mathrm{hr}^{-1}$, trips over $25 \mathrm{~km}$ of open water would have been reasonable with a maximum range of travel of less than $100 \mathrm{~km}$. Short hop, coastal voyages were likely, but long-distance, open-ocean voyages would have been impossible. Thus, frequent haul-outs would have been necessary, requiring closely spaced refugia.

A possible lack of suitably spaced refugia for haul-outs prior to $16,000 \mathrm{yr} \mathrm{BP}$ needs to be considered. Mariners likely would have encountered a vertical wall of ice at the glacial front in some areas that would not have provided an opportunity for boat haul-outs. Much of the Alaska/ British Columbia coast was covered by the CIS prior to about $14,000 \mathrm{yr}$ BP (Menounos et al., 2017). However, Lesnek et al. (2018) used ${ }^{10} \mathrm{Be}$ ages from southeastern Alaska to report that the CIS retreat had uncovered several nearshore islands at about 17,000 years BP. Therefore, these islands would not have been suitable for human habitation until after 17,000 yr BP (Lesnek et al., 2018). However, Darvill et al. (2018) found that along the British Columbia coastal margin by at least $17,000 \pm 300 \mathrm{yr} \mathrm{BP}$, numerous ice-free areas were exposed that could have provided a route for human travel. Because global sea level at 17,000 yr BP, as measured at Tahiti, was about $120 \mathrm{~m}$ below present sea level (Dechamps et al., 2012), some of the continental shelf in the Gulf of Alaska might also have been above sea level and therefore may have provided some of the essential refugia.

The exact configuration of the refugia for that time is complicated by isostatic responses of the land to glacial loading. The CIS created refugia in the form of forebulges that were established ahead of the advancing ice sheet. Forebulges are created as the weight of glacial ice depresses Earth's crust beneath it, with an accompanying uplift of Earth's crust forward of the ice front. Luternauer et al. (1989), Hetherington et al. (2003), and McLaren et al. (2014) have reported evidence of forebulges off the coast of British Columbia during the Last Glacial Maximum (LGM; Mix et al., 2001). Hetherington et al. (2003) described an uplift of more than $100 \mathrm{~m}$, with horizontal scales of hundreds of kilometers. In addition to these forebulges, there could have been seafloor uplift due to seismic activity along offshore faults in this tectonically active coastal region. Shugar et al. (2014) suggest that the continental shelf off Southeast Alaska may have responded to a combination of crustal deformation (neotectonics), changes in the volume of water in the ocean (eustasy), and Earth's crustal response to the ice sheets (isostasy), resulting in a sea level that may have been $165 \mathrm{~m}$ lower than today. Therefore, many refugia may have existed at the time of the LGM on the continental shelf of coastal Alaska and British Columbia.

A refinement of the forebulge process is a hinge concept in which the CIS created a downward crustal response beneath the ice sheet with an accompanying upward motion of forebulge offshore, with a hinge-like motion in between (Shugar et al., 2014). Hetherington and Barrie (2004) support the hinge concept and report $100 \mathrm{~m}$ of uplift related to forebulge growth west of the CIS off the coast of British Columbia. There is some evidence of this hinge today in Southeast Alaska. Today, Earth's crust continues to rebound from the melted CIS. The sea 
level at Juneau (178 km inland but connected to the ocean by estuarine passes) is decreasing by $13.19 \mathrm{~mm} \mathrm{yr}^{-1}$, whereas the sea level at Sitka (located at the coast)

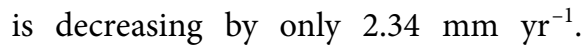
The region of the shelf that contained the uplifted LGM forebulges may have served as refugia for early Americans. Unfortunately, geological data to support this hypothesis have not yet been collected (Shugar et al., 2014). However, recognizing that sea level was at least $120 \mathrm{~m}$ lower than it is now, combined with a possible uplift of the seafloor, allows that there could have been sufficient areas of dry land available for islandhopping mariners in skin boats to transit the coastline of Alaska and British Columbia at about 16,000 yr BP.

\section{PHYSICAL OCEANOGRAPHIC INFLUENCES ON EARLY MIGRATION}

Any migration during the LGM and early deglaciation period may have been facilitated by altered coastal currents, which would have favored such travel for only a few millennia. Direct measurements of ocean circulation 14,000-18,000 yr BP are not available, though the driving mechanisms of winds and freshwater influxes were probably similar to conditions today, differing only in intensity. Today, the wind field is dominated by the large-scale Aleutian low-pressure system, with cyclonic winds and winter intensification that drive the offshore Alaska Current in a counterclockwise direction (that is, north and then west; Royer, 1982; Figure 1). Inshore of the Alaska Current, a parallel flow, propelled by both alongshore winds and freshwater discharges, drives the Alaska Coastal Current (ACC; Royer, 1981; Weingartner et al., 2005). These winds drive a primarily downwelling shelf circulation that maintains the ACC as a buoyancy and wind-driven alongshore flow. The ACC is the dominant circulation feature on the continental shelf of the Gulf of Alaska, with northward and then westward flows within about $20-30 \mathrm{~km}$ of the coast and current speeds in excess of $35 \mathrm{~cm} \mathrm{~s}^{-1}$ (Stabeno et al., 2016). Westward, alongshore peak current speeds in autumn of more than $140 \mathrm{~cm} \mathrm{~s}^{-1}$ at $2 \mathrm{~m}$ depth have been measured with 35-hour filtered values of more than $100 \mathrm{~cm} \mathrm{~s}^{-1}$ (Johnson and Royer, 1986). Freshwater is added from coastal runoff and rivers as the ACC flows northward and westward around the Gulf of Alaska and finally enters the Bering Sea (Royer, 1982). Annually, this intense nearshore current carries about $870 \mathrm{~km}^{3}$ of freshwater from precipitation and glacial meltwater (Neal et al., 2010), about 50\% more freshwater annually than is transported by the Mississippi River.

Prior to about $16,000 \mathrm{yr}$ BP, the amount of freshwater entering coastal Gulf of Alaska may have been much less than it is today. Freshwater inputs would have included precipitation falling directly on the ocean surface and runoff from coastal watersheds. Though the precipitation rates were likely lower than they are today, the runoff also would have been greatly reduced because a greater proportion of the precipitation falling on glacial ice fields would have added to the snow and ice mass rather than being discharged into the ocean, thereby minimizing the ACC flow. This coastal circulation condition would have created a more welcoming avenue for seafaring settlers with (1) a biologically productive marine ecosystem, (2) refugia created by offshore forebulges and sea levels more than $120 \mathrm{~m}$ lower than today, and (3) a greatly reduced or absent ACC.

As the LGM began to wane, the ACC may have become a serious hindrance to southward human migrations along the Gulf of Alaska coast. Freshwater discharge and hence the ACC would have accelerated during the Bølling-Allerød warming period. Climate changes associated with this period, starting at $14,650 \mathrm{yr} \mathrm{BP}$ (Deschamps et al., 2012), caused the CIS to melt at locations in the North Pacific where salinity has a greater influence on density than temperature and hence on ocean dynamics (Royer, 1982; Hickey and Royer, 2001). This phenomenon is a result of the nonlinearity of the equation of state of seawater (Millero, 2010). Increased

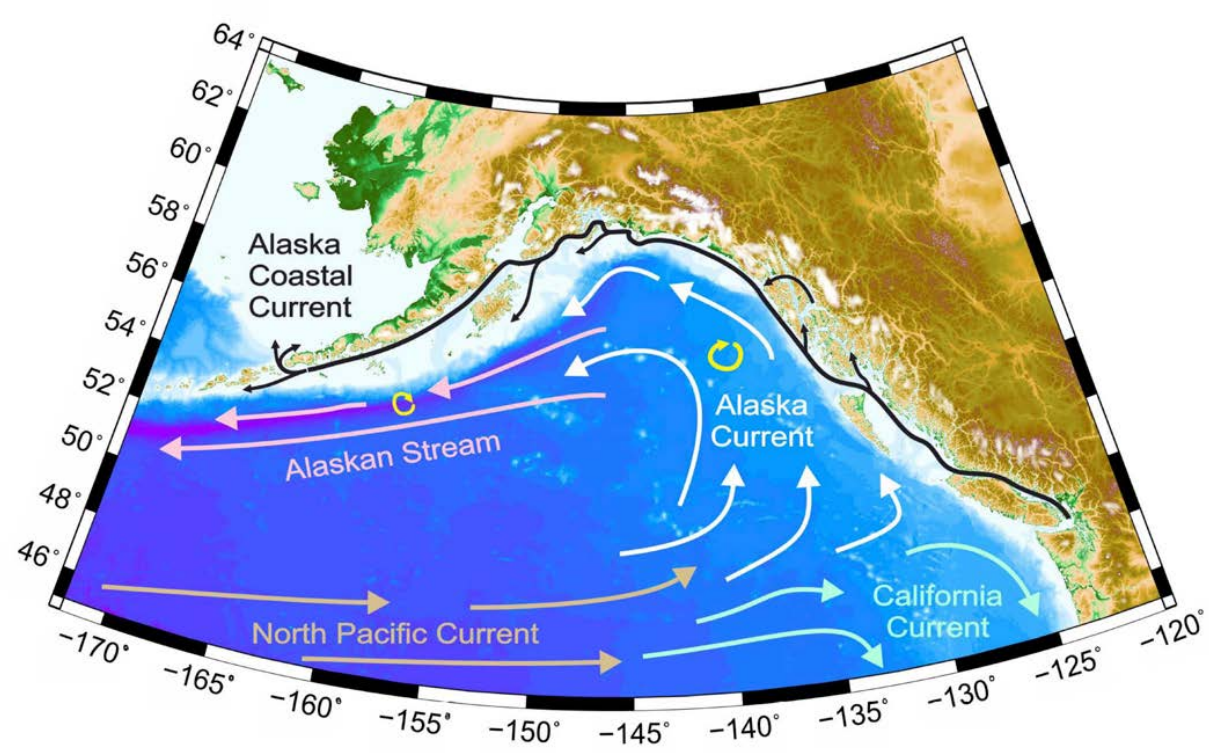

FIGURE 1. Ocean circulation in the Gulf of Alaska. The surface ocean currents flowing counterclockwise in the Gulf of Alaska include the North Pacific Current, the Alaska Current, the Alaskan Stream, and the Alaska Coastal Current (ACC). The ACC (depicted in black) is a narrow $(<30 \mathrm{~km})$, nearshore flow with speeds of the order of $100 \mathrm{~cm} \mathrm{~s}^{-1}$ near the coast. The ACC begins in the vicinity of the Washington-British Columbia border and carries precipitation and runoff, including snow and glacial meltwater, into the Bering Sea (Weingartner et al., 2005). The ACC now flows over continental shelves that might have served as haul-out regions for ancient mariners prior to 15,000 years before present. Figure courtesy of Seth Danielson, University of Alaska Fairbanks 
nearshore and alongshore melting would have strengthened the offshore horizontal density and pressure gradients, with the accompanying increased poleward flow of the warmer waters creating a positive feedback system. Warmer water transported northward would have increased the rate of glacial melting. Even in the absence of this positive feedback system, Truffer and Motyka (2016) argue that the heat from ocean sources available to melt tidewater glaciers is almost infinite. Additionally, the increased sea surface temperature could have supplied heat to the atmosphere and intensified the Aleutian low-pressure system, providing another positive feedback process driving the atmosphere-ocean system, further increasing the air temperature and precipitation rates. Therefore, melting of the CIS along the ocean-ice interface could have accelerated the alongshore, northward flow along the British Columbia and Southeast Alaska coasts, accelerating the CIS's melting. This increased glacial melting would have strengthened the ACC opposing eastward and southward travel along the coast of Alaska and British Columbia toward the present-day Americas.

\section{POST-LGM OCEANOGRAPHY OF THE GULF OF ALASKA}

To determine the ocean's responses to the Bølling-Allerød warming, we use an understanding of contemporary global glacial melting and its effects on global sea level (Table 1). Estimates of present-day annual runoff in the Gulf of Alaska from glacial melting range from $46 \mathrm{~km}^{3}$ to $100 \mathrm{~km}^{3}$. This annual water volume comprises $8 \%$ to $11 \%$ of the total global meltwater contribution to sea level rise. The percentage of the Alaskan contribution of meltwater to the present total global glacial meltwater is therefore assumed to be approximately $10 \%$. Some other studies of contemporary melting of glacial ice support the importance of glacial meltwater influxes into the Gulf of Alaska to global sea levels. Hill et al. (2015) determined that from 2004 to 2008 , glaciers in the northern region of the Gulf of Alaska alone contributed $57 \mathrm{~km}^{3} \mathrm{yr}^{-1}$ to the global ocean's volume. The importance of the Gulf of Alaska glacial meltwater to global meltwater input was also noted by Jacob et al. (2012) and Gardner et al. (2013), who used satellite gravimetry and altimetry as well as local records to estimate that from 2003 to 2009, Alaskan glaciers contributed the most meltwater to the ocean, excluding those in Antarctica and Greenland. The contributions of Alaskan glaciers to global sea level rise are therefore significant. The volume of glacial ice melt required to increase the global sea level by $1 \mathrm{~mm}$ in a year is estimated to be $360 \mathrm{~km}^{3}$ (from Table 1).

Changes in global sea level are the result not only of changes in the amount of water but also of changes in the water density due to steric changes (that is, changes in temperature and salinity). Contemporary non-steric sea level change estimates range from $1.8 \mathrm{~mm} \mathrm{yr}^{-1}$ (Meier et al., 2007) to $1.48 \mathrm{~mm} \mathrm{yr}^{-1}$ (Jacob et al., 2012). Knowledge of the present- day contribution of glacial melting in the Gulf of Alaska and its influence on contemporary sea level can be used to estimate Alaskan coastal conditions during the end of the LGM.

Ancient Gulf of Alaska glacial discharges are estimated using dating of global sea level change prior to 14,000 yr BP as constructed from temporal changes in the depth of coral reefs from Tahiti (Deschamps et al., 2012; Figure 2). A rapid sea level rise of 14-18 m occurred at Tahiti between 14,310 and 14,650 yr BP

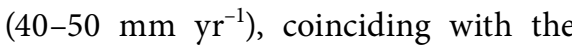
commencement of the Bølling-Allerød warming period and the Meltwater Pulse 1A (MWP-1A) period warming 14,600 yr BP. Assuming a global glacial ice loss to sea level rise rate of $360 \mathrm{~km}^{3}$ per millimeter of sea level rise from Table 1 , the $40-50 \mathrm{~mm} \mathrm{yr}^{-1}$ sea level rise would have required a $14,400-18,000 \mathrm{~km}^{3} \mathrm{yr}^{-1}$ change in global glacial volume during MWP-1A. This supports the estimates of about $15,000 \mathrm{~km}^{3} \mathrm{yr}^{-1}$ for this period by Lambeck et al. (2014) using the sea level change after the LGM from their Figure 4. In summary, global glacial ice melting of about $15,000 \mathrm{~km}^{3} \mathrm{yr}^{-1}$ was required to produce this sea level change during the 340 years of MWP-1A warming.

Based on present-day data, a $10 \%$ contribution of Alaskan glaciers to global sea level rise during the MWP-1A is estimated to have been about $1,500 \mathrm{~km}^{3} \mathrm{yr}^{-1}$. This coordination of Alaskan glacial melt within the broader CIS melt is supported by Davies-Walczak et al. ( 2014), though this volume is probably an underestimate

TABLE 1. Comparisons of the contributions of global and Alaskan glacial meltwater to sea level rise.

\begin{tabular}{|c|c|c|c|c|c|c|c|}
\hline Source & $\begin{array}{c}\text { Time Period } \\
\text { (yr) }\end{array}$ & $\begin{array}{c}\text { Global } \\
\text { Ice Mass } \\
\text { Change } \\
\left(\mathrm{km}^{3} \mathrm{yr}^{-1}\right)\end{array}$ & $\begin{array}{c}\text { Alaska } \\
\text { Glacial Mass } \\
\text { Change } \\
\left(\mathrm{km}^{3} \mathrm{yr}^{-1}\right)\end{array}$ & $\begin{array}{c}\text { Global } \\
\text { Sea Level Rise } \\
\text { Non-Steric } \\
\left(\mathrm{mm} \mathrm{yr^{-1 } )}\right.\end{array}$ & $\begin{array}{c}\text { Alaska } \\
\text { Sea Level Rise } \\
\left(\mathrm{mm} \mathrm{yr}^{-1}\right)\end{array}$ & $\begin{array}{c}\text { Alaska \% } \\
\text { of } \\
\text { Global Sea } \\
\text { Level Rise }\end{array}$ & $\begin{array}{c}\text { Glacial lce } \\
\text { Volume Change/ } \\
\text { Sea Level Rise } \\
\left(\mathrm{km}^{3} \mathrm{yr}^{-1} / \mathrm{mm}^{-1}\right)\end{array}$ \\
\hline Lambeck et al. (2014) & $15,000-14,000$ yr BP & 15,000 & 1,500 & $40-50$ & $4-5$ & 10 & 387 \\
\hline Arendt et al. (2002) & 1995-2001 & - & 96 & - & 0.27 & $8-9$ & - \\
\hline Neal et al. (2010) & $1990-2001$ & - & 87 & - & - & - & - \\
\hline Meier et al. (2007) & 2006 & 645 & 100 & 1.8 & 0.28 & 11.1 & 358 \\
\hline Jacob et al. (2012) & $2003-2010$ & 536 & 46 & 1.48 & 0.13 & 8.8 & 362 \\
\hline
\end{tabular}


because the CIS was a far more dominant feature during MWP-1A than are the Alaskan ice fields of today (Clague, 2009), and there were more tidewater glaciers. An estimate of present-day total freshwater discharge into the Gulf of Alaska is $27,600 \mathrm{~m}^{3} \mathrm{~s}^{-1}$ or $870 \mathrm{~km}^{3} \mathrm{yr}^{-1}$, with $10 \%$ of it as glacial meltwater (Neal et al., 2010). Substituting this meltwater rate with the glacial meltwater estimated 14,000-15,000 yr BP, the average annual Gulf of Alaska freshwater contribution to the ocean would have been $2,283 \mathrm{~km}^{3} \mathrm{yr}^{-1}$ or $72,300 \mathrm{~m}^{3} \mathrm{~s}^{-1}$ averaged over 340 years. If the glacial melting took place for only nine months of the year, the discharge could have reached about $93,000 \mathrm{~m}^{3} \mathrm{~s}^{-1}$. (For a contemporary comparison, there are five months of snow accumulation annually in Juneau, Alaska; http://climate.gi.alaska.edu/Climate/ Normals). Thus, glacial meltwater would have been more than an order of magnitude greater than today and would have produced a total freshwater discharge that was, for 340 years, about triple the discharge today.

Reconstruction of past salinity in the Gulf of Alaska between 15,000 yr BP and 14,000 yr BP from coastal sediment core data supports this freshening hypothesis. Sediment core data indicate that at $14,450 \pm 290$ yr BP, significant changes in the hydrographic structure in the coastal water column took place in the Gulf of Alaska (Davies et al., 2011). A piston core (EW0408 85JC) was obtained at $682 \mathrm{~m}$ water depth offshore of the present-day Bering Glacier $\left(59^{\circ} 33.32^{\prime} \mathrm{N}\right.$, $144^{\circ} 9.21^{\prime} \mathrm{W}$ ) during a 2004 research cruise on R/V Maurice Ewing. An abrupt decrease of 1 ppt (part per thousand) is recorded by the benthic foraminifera $\delta^{18} \mathrm{O}$ at $14,450 \mathrm{yr}$ BP. This occurrence was either a signal from an abrupt bottom water temperature increase of about $5^{\circ} \mathrm{C}$ (unlikely) or a reduction in the bottom salinity of about 1 psu. Davies et al. (2011) present three possible explanations for this salinity event: (1) local formation of isotopically depleted brines from sea ice formation with their ultimate sink- ing, (2) deepening of the halocline, or (3) hyperpycnal flows. The ice formation hypothesis is unlikely because this was the time of the Bølling-Allerød warming (Deschamps et al., 2012; Gregoire et al., 2016), coincident with a $3^{\circ} \mathrm{C}$ increase in sea surface temperature off Vancouver Island (Taylor et al., 2014). Davies et al. (2011) initially eliminated the possible deepening of the halocline because it would have required an order of magnitude greater freshwater input into the Gulf of Alaska than is estimated for present times. Thus, hyperpycnal flows, by default, were assumed to be the cause of this $\delta^{18} \mathrm{O}$ layer (Maureen Davies, Oregon State University, pers. comm., 2016).

The second hypothesis of Davies et al. (2011), however, provides the best explanation in light of increased Gulf of Alaska freshwater discharges predicted by MWP-1A sea level changes. The $\delta^{18} \mathrm{O}$ changes are consistent with our reconstructed freshwater influxes into the Gulf of Alaska at that time. Also, the western limit of the CIS probably extended onto the continental shelf at that time due to lowered sea level (Clague, 2009), forcing
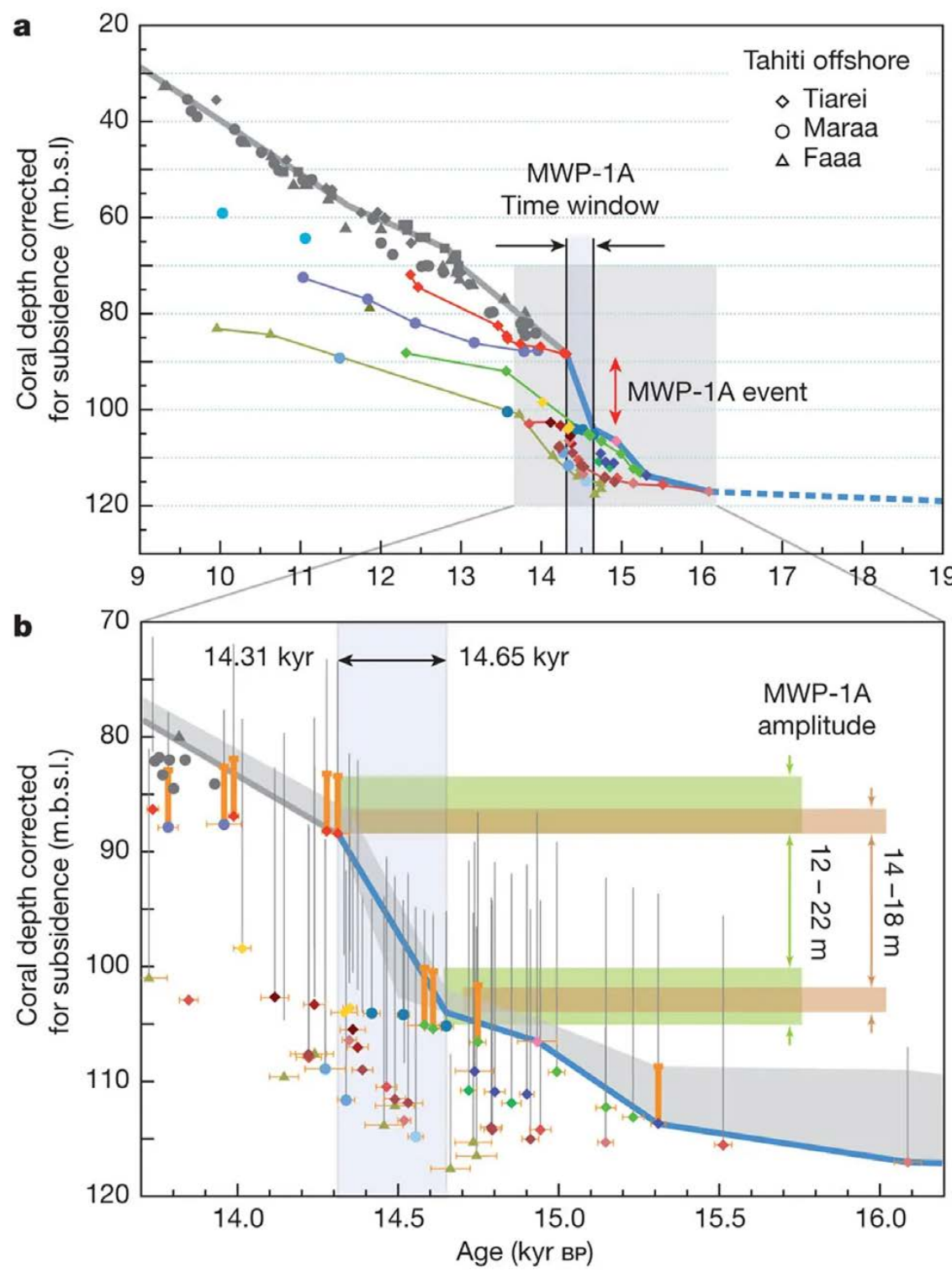

FIGURE 2. Tahiti sea levels 19,000-9,000 years before present (yr BP). The inset shows the rapid rise in sea level from $14,650 \mathrm{yr}$ BP to $14,310 \mathrm{yr}$ BP (14.65 kyr BP to $14.31 \mathrm{kyr} \mathrm{BP}$ ), called Meltwater Pulse 1A (MPW-1A), during the Bølling-Allerød warming. m.b.s.l. = meters below sea level. From Deschamps et al. (2012) 
the axis or core of the ACC to be close to the location of core EW0408 85JC. Assuming that global sea level was at least $125 \mathrm{~m}$ lower than at present (Deschamps et al., 2012), the core location would have been within $19 \mathrm{~km}$ of the LGM coastline, though determining the exact paleogeography of the site at this time is complicated by eustatic, isostatic, and ice-gravitational effects (Kendell et al., 2005). Thus, Davies et al. (2011) assumed the axis of the ACC was very close to the benthic core site rather than more than $100 \mathrm{~km}$ away from it. Also, there may have been a forebulge ahead of the glacier that raised the seafloor by tens to hundreds of meters (Shugar et al., 2014). This shallower depth would not have required an immense volume of freshwater to freshen the waters near the seafloor. The rate determined from global sea level changes $\left(93,000 \mathrm{~m}^{3} \mathrm{~s}^{-1}\right)$ exceeds the freshwater discharge estimate of $92,000 \mathrm{~m}^{3} \mathrm{~s}^{-1}$, which Davies et al. (2011) calculated to explain the decrease in salinity implied by the $\delta^{18} \mathrm{O}$ changes. Therefore, the salinity decrease Davies et al. (2011) reported was probably the result of glacial meltwater, and this conclusion is supported by the Gulf of Alaska freshwater estimate made using ancient sea level measurements and contemporary measurements of changes in glacial ice mass and sea level.

\section{OTHER SUPPORTING EVIDENCE OF IMPACTS ON EARLY SETTLERS IN THE COASTAL CORRIDOR AND REFUGIA}

Gulf of Alaska glacial meltwater probably impacted the migrations of early humans to the Americas in several ways. During the LGM, greatly reduced glacial melting and runoff would have minimized alongshore flow of the ACC and provided easier travel eastward and southward along the coast from Beringia. As the LGM ended and deglaciation intensified as the Bølling-Allerød period began, the time of easy coastal passage ceased. There would have been (1) rapidly rising global sea levels, (2) increased CIS melting contributing more than an order of magni- tude more freshwater into the ACC, and (3) an acceleration of the ACC. Both current speeds and current widths should have increased. Additional poleward heat transport by the ocean could have increased the intensity of the Aleutian Low, further strengthening the winds and precipitation rate, and enhancing opposing (poleward) coastal currents. However, the most critical change in the oceanography might have been the rapidly rising sea level that submerged the refugia, making the required transits too great for skin boat travel.

Several recent papers have addressed archaeological and genetic evidence of early coastal migrations. The timings of the initial migrations into the Americas are supported by evidence of early settlement (e.g., Monte Verde South America by 14,500 yr BP), after a moderate genetic bottleneck in Beringia about 23,000-19,000 yr BP followed by a rapid population expansion between $18,000 \mathrm{yr}$ BP and 15,000 yr BP (Fagundes et al., 2008, 2018; Moreno-Mayar et al., 2018; Braje et al., 2019). This strong population expansion, which ended $\sim 15,000$ yr BP, supports pre-Clovis occupation of the New World and suggests rapid settlement of North and South America by humans following a Pacific coastal route. Llamas et al. (2016) state that, "We knew that Native Americans living today have a relatively low genetic diversity, meaning it is highly likely that sometime in the past, they lost some of their genetic diversity in what we call a bottleneck." A small population may have entered the Americas via the coastal route around $16,000 \mathrm{yr}$ BP. This is supported by early dates at several sites, including the Columbia River basin in western Idaho (16,560 yr BP to $15,280 \mathrm{yr}$ BP; Davis et al., 2019); Manis, Washington (Waters et al., 2011); coastal British Columbia (McLaren et al., 2019); Monte Verde (Chile); and others. These data reinforce the concept that the Americas were settled prior to 13,000 yr BP (Wade, 2017), before the opening of the passage between the Laurentide and Cordilleran
Ice Sheets. Using ancient DNA, pollen, and plant remains, Pedersen et al. (2016) established the timing of the opening of the $1,500 \mathrm{~km}$-long land corridor through Canada as 12,600 yr BP, though evidence for somewhat earlier passage is possible (Potter et al., 2018). Pedersen et al. (2016) suggest possible settlement models that include one consistent with the timing of early marine migrations prior to $14,000 \mathrm{yr} \mathrm{BP}$ as a single wave along the coastal route, with later terrestrial migrations in the ice-free corridor between the ice sheets.

Other Late Pleistocene technological linkages and traditions that date prior to opening of the land corridor have been found in coastal locations in North and South America (Erlandson and Braje, 2011). The initial Pleistocene migrations into the Americas may have occurred within a narrow time window of no more than 2,000 years. The succession of temporally distinct movements along the coastal route between 17,000 yr BP and 15,000 yr BP (Perego et al., 2009) coincided with lowered sea level and relatively small alongshore coastal flows, making coastal refugia available. This window of opportunity closed at the onset of the Bølling-Allerød warm period, which melted glaciers and caused high freshwater influxes that drove strong northerly alongshore flows. Recent highresolution DNA analyses allow a finer estimate of the timing of early settlement of the Americas. Llamas et al. (2016) determined that early settlement began about $16,000 \mathrm{yr}$ BP and ended less than 2,000 years later (about $14,000 \mathrm{yr} \mathrm{BP}$ ). In sum, this body of evidence supports the idea of a brief pre-15,000 yr BP coastal marine route for early Americans, prior to the rapid melting of the CIS in the Gulf of Alaska. McLaren et al. (2019) outline a stepwise process to aid in discovering Pleistocene archaeological sites along the Pacific coast of North America in the search for sites that predate $14,000 \mathrm{yr}$ BP. The recent review by Froese et al. (2019) on geological evidence concluded it was more likely that prior to 
15,000 yr BP-14,500 yr BP, the first peoples traversed from Beringia by way of the coastal route rather than through the ice-free corridor between the Cordilleran and Laurentide Ice Sheets.

\section{CONCLUSIONS}

The timing of migration into Beringia, boat development, and changes in ocean conditions along the Northeast Pacific coastline are consistent with the possibility of an initial migration into the Americas prior to the Bølling-Allerød warm period. This period was also a time when "a coastal avenue to the Americas" was open for travel. At some time after 15,000 yr BP, however, these travels would have been much more difficult due to rapidly rising sea levels and stronger opposing flows in the Alaska Coastal Current that created serious constraints to this southward migration. This migration hiatus might have continued until sufficiently closely spaced, ice-free coastal areas emerged from beneath the melting CIS and the volume of CIS meltwater diminished, reducing the strength of the ACC. Once again, safe coastal passage along the Alaskan and British Columbia coasts would have been possible during the Younger Dryas and after the Melt Water Pulse 1B ( 11,300 yr BP). The current chronology of human settlement in the Americas is consistent with this proposed timing of "ocean avenues."

Any coastal migrants to the Americas must have been capable of designing and constructing seaworthy boats to navigate along the coastal route from Beringia to the Pacific Northwest toward ultimate settlement in the Americas. Their coastal migrations were possibly halted by climate change during the BøllingAllerød warming period that led to melting of the global ice sheets, including the CIS over western North America. Rising global sea levels drowned the original coastal refugia, and the increased regional freshwater flows led to escalated coastal currents that also obstructed the pathways. A hiatus in the use of this eastward and southward waterway probably lasted for several thousand years, prohibiting new settlers to the Americas but allowing northward passage back to Beringia. It seems likely that early migrants to the Americas were victims of a severe climate change when sea levels rose at $40-50 \mathrm{~mm} \mathrm{yr}^{-1}$ for 340 years, more than an order of magnitude greater than our present-day sea level rise of about $3 \mathrm{~mm} \mathrm{yr}^{-1}$.

\section{RECOMMENDED FUTURE STUDIES}

The lack of adequate research vessels and access to logistical resources and personnel has caused the Southeast Alaska continental shelf region to be an understudied part of the Northeast Pacific Ocean. The following problems/questions might be addressed to resolve whether this route was truly a travel or settlement corridor for early Americans:

- Do shell middens, stone fish weirs, and structures exist beneath meters of glacial sediments, particularly within submerged flow channels?

- Can sub-bottom seismic profiling and coring be used as effective tools to investigate for possible prehistoric underwater archaeology features (e.g., Dixon and Monteleone, 2014)?

- Can local sea level curves, elevation models, and archaeological site prediction models be used to locate subaerial coastal sites documenting early human occupation (e.g., McLaren et al., 2019)?

- Will studies of tectonic features and sediment cores verify the existence of regional Quaternary forebulges and lead to a better understanding of Northeast Pacific plate tectonics and coastal refugia?

- Can satellite measurements of shelf bottom topography in the Gulf of Alaska be used to detect the shelf hinges of bottom displacements?

- How did freshwater flux into the Gulf of the Alaska vary from the LGM to present? Such reconstructions require knowledge of the history of both glacial meltwater and precipitation.
- Can reconstructions of CIS deglaciation and ice volume be used to refine the meltwater calculations (e.g., Tarasov et al., 2012)?

- Can atmospheric circulation models and paleoclimatic data be used to quantify past changes in precipitation in Northeast Pacific watersheds?

- What was the ancient variability of the ACC during this period in response to the estimated large changes in glacial meltwater and climate?

- What were the current velocities after the LGM, and how might the flows have been distributed across the shelf and seasonally?

- Were seasonal melt variations amplified during the transition from the LGM to the Holocene?

- How might atmospheric circulation and resultant changes in precipitation and productivity have been different from today?

- What were the differences and similarities in the ancient marine ecosystem as compared to today?

\section{REFERENCES}

Arendt, A.A., K.A. Echelmeyer, W.D. Harrison, C.S. Lingle, and V.B. Valentine. 2002. Rapid wastage of Alaska glaciers and their contribution to rising sea level. Science 287(5580):382-386, https://doi.org/10.1126/science.1072497.

Bourgeon, L., A. Burke, and T. Higham. 2017. Earliest human presence in North America dated to the Last Glacial Maximum: New radiocarbon dates from Bluefish Caves, Canada. PLOS ONE 12(1):e0169486, https://doi.org/10.1371/journal.pone.0169486.

Braje, T.J., D. Dillehay, J.M. Erlandson, R.G. Klein, and T.C. Rick. 2017. Finding the first Americans. Science 58(6363):592-594, https://doi.org/10.1126/ science.aao5473.

Braje, T.J., C.R. Torben, T.D. Dillehay, J.M. Erlandson, and R.G. Klein. 2018. Arrival routes of first Americans uncertain-Response. Science 359(6381):1,225, https://doi.org/10.1126/ science.aar8645.

Braje, T.J., J.M. Erlandson, T.C. Rick, L. Davis, T. Dillehay, D.W. Fedje, D. Froese, A. Gusick,

Q. Mackie, D. McLaren, and others. 2019. Fladmark + 40: What have we learned about a potential Pacific coast peopling of the Americas? American Antiquity, https://doi.org/10.1017/aaq.2019.80.

Braund, S.R. 1988. The Skin Boats of Saint Lawrence Island. University of Washington Press, Seattle, WA, $121 \mathrm{pp}$.

Clague, J.J. 2009. Cordilleran ice sheet. Pp. 206-211 in Encyclopedia of Paleoclimatology and Ancient Environments. V. Gornitz, ed., Springer, Dordrecht, The Netherlands.

Darvill, C.M., B. Menounos, B.M. Goehring, O.B. Lian, and M.W. Caffee. 2018. Retreat of the western Cordilleran ice sheet margin during 
the last deglaciation. Geophysical Research Letters 45(18):9,710-9,720, https://doi.org/10.1029/ 2018 GL079419.

Davies, M.H., A.C. Mix, J.S. Stoner, J.A. Addison, J. Jaeger, B. Finney, and J. Wiest. 2011. The deglacial transition on the southeastern Alaska Margin: Meltwater input, sea level rise, marine productivity, and sedimentary anoxia. Paleoceanography 26(2), https://doi.org/10.1029/2010PA002051.

Davies-Walczak, M., A.C. Mix, J.S. Stoner, J.R. Southon, M. Cheseby, and C. Xuana. 2014. Late Glacial to Holocene radiocarbon constraints on North Pacific Intermediate Water ventilation and deglacial atmospheric $\mathrm{CO}_{2}$ sources. Earth and Planetary Science Letters 397:57-66, https://doi.org/10.1016/j.epsl.2014.04.004.

Davis, L.G., D.B. Madsen, L. Becerra-Valdivia, T. Higham, D.A. Sisson, S.M. Skinner, D. Stueber. A.J. Nyers, A. Keen-Zebert, C. Neudorf, and others. 2019. Late Upper Paleolithic occupation at Cooper's Ferry, Idaho, USA, 16,000 years ago. Science 365(6456):891-897, https://doi.org/10.1126/ science.aax9830.

Deschamps, P., N. Durand, E. Bard, B. Hamelin, G. Camoin, A.L. Thomas, G.M. Henderson, J. Okuno, and Y. Yokoyama. 2012. Ice-sheet collapse and sea-level rise at the Bølling warming 14,600 years ago. Nature 483:559-564, https://doi.org/10.1038/nature10902.

Dixon, E.J. 2000. Bones, Boats \& Bison: Archeology and the First Colonization of Western North America. University of New Mexico Press, Albuquerque, $322 \mathrm{pp}$.

Dixon, E.J., and K. Monteleone. 2014. Gateway to the Americas: Underwater archeological survey in Beringia and the North Pacific. Pp. 95-114 in Prehistoric Archaeology on the Continental Shelf. A.M. Evans, J.C. Flatman, and N.C. Flemming, eds, Springer, New York.

Erlandson, J.M., M.H. Graham, B.J. Bourque, D. Corbett, J.A. Estes, and R.S. Steneck. 2007. The kelp highway hypothesis: Marine ecology, the coastal migration theory, and the peopling of the Americas. Journal of Island and Coastal Archaeology 2:161-174, https://doi.org/ 10.1080/15564890701628612.

Erlandson, J.M., M.L. Moss, and M. Des Lauriers. 2008. Life on the edge: Early maritime cultures of the Pacific Coast of North America. Quaternary Science Reviews 27(23-24):2,232-2,245, https://doi.org/10.1016/j.quascirev.2008.08.014.

Erlandson, J.M., and T.J. Braje. 2011. From Asia to the Americas by boat? Paleogeography, paleoecology, and stemmed points of the Northwest Pacific. Quaternary International 239:28-37, https://doi.org/10.1016/j.quaint.2011.02.030.

Erlandson, J.M., T.J. Braje, K.M. Gill, and M.H. Graham. 2015. Ecology of the kelp highway: Did marine resources facilitate human dispersal from Northeast Asia to the Americas? The Journal of Island and Coastal Archaeology 10(3):392-411, https://doi.org/10.1080/15564894.2014.1001923.

Fagundes, N.J.R., R. Kanitz, R. Eckert, A.C.S. Valls, M.R. Bogo, F.M. Salzano, D.G. Smith, W.A. Silva Jr., M.A. Zago, A.K. Ribeiro-dos-Santos, and others. 2008. Mitochondrial population genomics supports a single pre-Clovis origin with a coastal route for the peopling of the Americas. The American Journal of Human Genetics 82:583-592, https://doi.org/10.1016/j.ajhg.2007.11.013.

Fagundes, N.R.J., A. Tagliani-Ribeiro, R. Rubicz, L. Tarskaia, M.H. Crawford, F.M. Salzano, and S.L. Bonatto. 2018. How strong was the bottleneck associated to the peopling of the Americas? New insights from multilocus sequence data. Genetics and Molecular Biology 41(1):supl.1, https://doi.org/ 10.1590/1678-4685-gmb-2017-0087.
Froese, D., J.M Young, S.L Norris, and M. Margold. 2019. Availability and viability of the ice-free corridor and Pacific coast routes for the peopling of the Americas. The SAA Archaeological Record 19(3):27-33.

Gardner, A.S., G. Moholdt, G. Cogley, B. Wouters, A.A. Arendt, J. Wahr, E. Berthier, R. Hock, W.T. Pfeffer, G. Kaser, and others. 2013. A reconciled estimate of glacier contributions to sea level rise: 2003 to 2009 . Science 340(6134):852-857, https://doi.org/10.1126/science.1234532.

Gregoire, L.J., B. Otto-Bliesner, P.J. Valdes, and R. Ivanovic. 2016. Abrupt Bølling warming and ice saddle collapse contributions to the Meltwater Pulse 1a rapid sea level rise. Geophysical Research Letters 43:9,130-9,137, https://doi.org/ 10.1002/2016GL070356.

Hetherington, R., J.V. Barrie, R.G.B. Reid, R. MacLeod D.J. Smith, T.S. James, and R. Kung. 2003. Queen Charlotte Islands, British Columbia, Canada, and its implications for terrestrial biogeography and early postglacial human occupation. Canadian Journal of Earth Science 40:1,755-1,766, https://doi.org/ 10.1139/E03-071.

Hetherington, R., and J.V. Barrie. 2004. Interaction between local tectonics and glacial unloading on the Pacific margin of Canada. Quaternary International 120:65-77, https://doi.org/10.1016/ j.quaint.2004.01.007.

Hickey, B.M., and T.C. Royer. 2001. California and Alaska currents. Pp. 78-84 in Encyclopedia of Ocean Sciences. Academic Press, London.

Hill, D.F., N. Bruhis, S.E. Calos, A.A. Arendt, and J. Beamer. 2015. Spatial and temporal variability of freshwater discharge into the Gulf of Alaska. Journal of Geophysical Research 120:634-646, https://doi.org/10.1002/2014JC010395.

Hoffecker, J.F. 2005. Innovation and technological knowledge in the Upper Paleolithic of northern Eurasia. Evolutionary Anthropology: Issues, News, and Reviews 14(5):186-198, https://doi.org/10.1002/ evan. 20066.

Jacob, T., J. Wahr, W.T. Pfeffer, and S. Swenson. 2012 Recent contributions of glaciers and ice caps to sea level rise. Nature 482:514-518, https://doi.org/ 10.1038/nature10847.

Johnson, W.R., and T.C. Royer. 1986. A comparison of two current meters on a surface mooring. Deep Sea Research Part A 33:1,127-1,138, https://doi.org/ 10.1016/0198-0149(86)90034-8.

Johnstone, P. 1988. The Sea-Craft of Prehistory. Routledge, London, 264 pp.

Kendall, R.A., J.X. Mitrovica, and G.A. Milne. 2005. On post-glacial sea level: Part II. Numerical formulation and comparative results on spherically symmetric models. Geophysical Journal International 161:679-706, https://doi.org/10.1111/ j.1365-246X.2005.02553.x.

Lambeck, K., H. Rouby, A. Purcell, Y. Sun, and M. Sambridge. 2014. Sea level and global ice volumes from the Last Glacial Maximum to the Holocene. Proceedings of the National Academy of Sciences of the United States of America 111(43):15,296-15,303, https://doi.org/ 10.1073/pnas.1411762111.

Lesnek, A.J., J.P. Briner, C. Lindqvist, J.F. Baichtal, and T.H. Heaton. 2018. Deglaciation of the Pacific coastal corridor directly preceded the human colonization of the Americas. Science Advances 4:eaar5040, https://doi.org/10.1126/ sciadv.aar5040.

Llamas, B., L. Fehren-Schmitz, G. Valverde, J. Soubrier, S. Mallick, N. Rohland, S. Nordenfelt, C. Valdiosera, S. Richards, A. Rohrlach, and others. 2016. Ancient mitochondrial DNA provides high-resolution time scale of the peopling of the Americas. Science Advances 2:e1501385, https://doi.org/10.1126/sciadv.1501385.
Luternauer, J.L., J.J. Clague, K.W. Conway, J.V. Barrie, B. Blaise, and R.W. Mathewes. 1989. Late Pleistocene terrestrial deposits on the continental shelf of western Canada: Evidence for rapid sea-level change at the end of the last glaciation. Geology 17(4):357-360, https://doi.org/10.1130/ 0091-7613(1989)017<0357:LPTDOT>2.3.CO;2.

McLaren, D., D. Fedje, M.B. Hay, Q. Mackie, I.J. Walker, D.H. Shugar, J.B. Eamer, O.B. Lian, and C. Neudorf. 2014. A post-glacial sea level hinge on the central Pacific coast of Canada. Quaternary Science Reviews 97:148-169, https://doi.org/10.1016/ j.quascirev.2014.05.023.

McLaren, D., D. Fedje, Q. Mackie, L.G. Davis, J. Erlandson, A. Gauvreau, and C. Vogelaar. 2019. Late Pleistocene archaeological discovery models on the Pacific Coast of North America. PaleoAmerica, https://doi.org/10.1080/20555563. 2019.1670512.

Meier, M., M.B. Dyurgerov, U.K. Rick, S. O’Neel, W.T. Pfeffer, R.S. Anderson, S.P. Anderson, and A.F. Glazovsky. 2007. Glaciers dominate eustatic sea-level rise in the $21^{\text {st }}$ century. Science 317(5841):1,064-1,067, https://doi.org/ 10.1126/science.1143906.

Menounos, B., B.M. Goehring, G. Osborn,

M. Margold, B. Ward, J. Bond, G.K.C. Clarke, J.J. Clague, T. Lakeman, J. Koch, and others. 2017. Cordilleran Ice Sheet mass loss preceded climate reversals near the Pleistocene Termination. Science 358(6364):781-784, https://doi.org/10.1126/ science.aan3001.

Millero, F.J. 2010. History of the equation of state of seawater. Oceanography 23(3):18-33, https://doi.org/10.5670/oceanog.2010.21.

Mix, A.C., E. Bard, and R. Schneider. 2001. Environmental processes of the ice age: Land, oceans, glaciers (EPILOG). Quaternary Science Reviews 20(4):627-657, https://doi.org/10.1016/ S0277-3791(00)00145-1.

Moreno-Mayar, J.V, B.A. Potter, L. Vinner, M. Steinrücken, S. Rasmussen, J. Terhorst, J.A. Kamm, A. Albrechtsen, A. Malaspinas, M. Sikora, and others. 2018. Early human dispersals within the Americas. Science 362(6419):eaav2621, https://doi.org/10.1126/science.aav2621.

Neal, E.G., E. Hood, and K. Smikrud. 2010. Contribution of glacier runoff to freshwater discharge into the Gulf of Alaska. Geophysical Research Letters 37(6), https://doi.org/10.1029/ 2010 GL042385.

Pedersen, M.W., A. Ruter, C. Schweger, H. Friebe, R.A. Staff, K.K. Kjeldsen, M.L.Z. Mendoza, A.B. Beaudoin, C. Zutter, N.K. Larsen, and others. 2016. Postglacial viability and colonization in North America's ice-free corridor. Nature 537:45-49, https://doi.org/10.1038/nature19085.

Perego, U.A., A. Achilli, N. Angerhofer, M. Accetturo, M. Pala, A. Olivieri, B.H. Kashani, K.H. Ritchie, R. Scozzari, Q. Kong, and others. 2009. Distinctive Paleo-Indian migration routes from Beringia marked by two Rare mtDNA haplogroups. Current Biology 19:1-8, https://doi.org/10.1016/ j.cub.2008.11.058.

Potter, B.A., A.B. Beaudoin, C.V. Haynes, V.T. Holliday, C.E. Holmes, J.W. Ives, R. Kelly, B. Llamas, R. Malhi, S. Miller, and others. 2018. Arrival routes of Americans uncertain. Science 359(6381):1,224-1,225, https://doi.org/ 10.1126/science.aar8233.

Royer, T.C. 1981. Baroclinic transport in the Gulf of Alaska: Part II. Fresh water driven Alaska Coastal Current. Journal of Marine Research 39:251-266.

Royer, T.C. 1982. Coastal fresh water discharge in the Northeast Pacific. Journal of Geophysical Research 87:2,017-2,021, https://doi.org/10.1029/ JC087iC03p02017. 
Shugar, D.H., I.J. Walker, O.B. Lian, J.B.R. Eamer, C. Neudorf, D. McLaren, and D. Fedje. 2014. Post-glacial sea-level change along the Pacific coast of North America. Quaternary Science Reviews 97:170-192, https://doi.org/10.1016/ j.quascirev.2014.05.022.

Stabeno, P.J., S. Bell, W. Cheng, S. Danielson, N.B. Kachel, C.W. Mordy. 2016. Long-term observations of Alaska Coastal Current in the northern Gulf of Alaska. Deep Sea Research Part // 32:24-40, https://doi.org/10.1016/j.dsr2.2015.12.016.

Sutton, M.Q. 2018. Paleoindian colonization by boat? Refining the coastal model. PaleoAmerica 4(4):325-339, https://doi.org/ 10.1080/20555563.2019.1565750.

Tarasov, L., A.S. Dyke, R.M. Neal, and W.R. Peltier. 2012. A data-calibrated distribution of deglacial chronologies for the North American ice complex from glaciological modeling. Earth and Planetary Science Letters 315-316:30-40, https://doi.org/ 10.1016/j.epsl.2011.09.010.

Taylor, M.A., I.L. Hendy, and D.K. Pak. 2014. Deglacia ocean warming and marine margin retreat of the Cordilleran Ice Sheet in the North Pacific Ocean. Earth and Planetary Science Letters 403:89-98, https://doi.org/10.1016/j.epsl.2014.06.026.

Truffer, M., and R.J. Motyka. 2016. Where glaciers meet water: Subaqueous melt and its relevance to glaciers in various settings. Reviews of Geophysics 54(1):220-239, https://doi.org/ 10.1002/2015RG000494.

Tsutsumi, T. 2007. The dynamics of obsidian use by the microblade industries of the terminal late Paleolithic. The Quaternary Research (Special Issue) 46(3):179-186, https://doi.org/10.4116 jaqua. 46.179 .
Wade, L. 2017. On the trail of ancient mariners. Science 357(6351):542-545, https://doi.org/10.1126/ science.357.6351.542.

Waters, M.R., T.W. Stafford Jr., H.G. McDonald, C. Gustafson, M. Rasmussen, E. Cappellini, J.V. Olsen, D. Szklarczyk, L.J. Jensen, M.T.P. Gilbert, and E. Willerslev. 2011. Pre-Clovis mastodon hunting 13,800 years ago at the Manis Site, Washington. Science 334:351-353, https://doi.org/10.1126 science.1207663.

Waters, M.R. 2019. Late Pleistocene exploration and settlement of the Americas by modern humans. Science 365:eaat5447, https://science.sciencemag. org/content/365/6449/eaat5447.

Weingartner, T.J., S.L. Danielson, and T.C. Royer. 2005. Freshwater variability and predictability in the Alaska Coastal Current. Deep Sea Research Part // 52:169-191, https://doi.org/10.1016/j.dsr2. 2004.09.030.

Wheat, A.D. 2012. Survey of professional opinions regarding the peopling of the Americas. The SAA Archaeological Record 12(2):10-14.

\section{ACKNOWLEDGMENTS}

We thank Nancy Yawes Davis for introducing TR to the possible routes of early Americans in her "Paths Across the Pacific" conference series in Sitka, Alaska. Collaborations with Fred Hope, a Tlingit elder, which took place during those conferences, led to the concept that massive coastal flooding took place in the past in coastal Alaska. BF acknowledges support from the US National Science Foundation (award number 1521365). We thank Seth Danielson of the College of Fisheries and Ocean Sciences at the University of Alaska Fairbanks for use of Figure 1. David Welch, Pat Tester, and Thomas Weingartner provided valuable suggestions on earlier versions of this manuscript. Lee Masover assisted TR with he editing skills and their unceasing discussions on early Americans. Three anonymous reviewers and reviews by Jon Erlandson and Maureen Davies-Walczak provided insightful and encouraging comments. We thank them all. The Center for Coastal Physical Oceanography, Old Dominion University, provided computer and library support for TR.

\section{AUTHORS}

Thomas C. Royer (royer@ccpo.odu.edu) is Professor Emeritus, Old Dominion University, Norfolk, VA, USA, and the University of Alaska Fairbanks, Fairbanks,

AK, USA. Bruce Finney (finney@isu.edu) is Professor, Idaho State University, Pocatello, ID, USA

\section{ARTICLE CITATION}

Royer, T.C., and B. Finney. 2020. An oceanographic perspective on early human migrations to the Americas. Oceanography 33(1):32-41, https://doi.org/ 10.5670/oceanog.2020.102.

\section{COPYRIGHT \& USAGE}

This is an open access article made available unde the terms of the Creative Commons Attribution 4.0 International License (https://creativecommons.org/ licenses/by/4.0/), which permits use, sharing, adaptation, distribution, and reproduction in any medium or format as long as users cite the materials appropriately, provide a link to the Creative Commons license, and indicate the changes that were made to the original content.

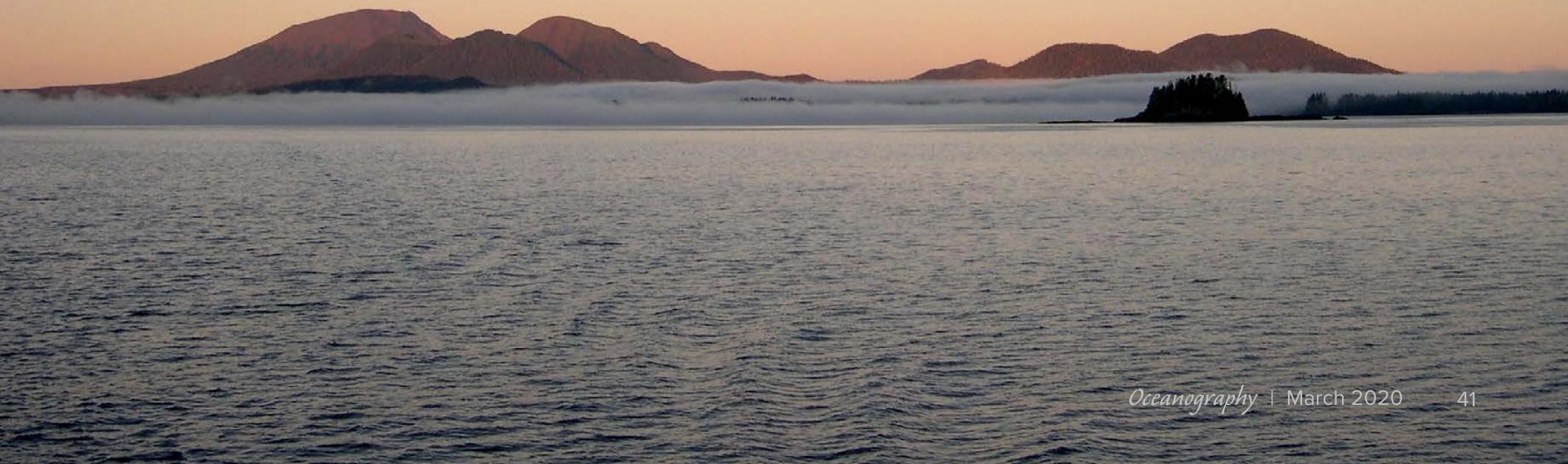

